\title{
IL-1 $\alpha$ and TNF $\alpha$ Act Synergistically to Stimulate Production of Myeloid Colony-Stimulating Factors by Cultured Human Bone Marrow Stromal Cells and Cloned Stromal Cell Strains
}

\author{
JERRY CALDWELL AND STEPHEN G. EMERSON* \\ Department of Internal Medicine and Pediatrics (S.G.E.) and Graduate Program in Cellular \\ and Molecular Biology (I.C.), University of Michigan, Ann Arbor, Michigan 48109
}

\begin{abstract}
Human bone marrow stromal cells repond to stimulation by the monokines IL-1 and TNF by producing colony-stimulating factors such as GM-CSF and G-CSF. In this study we show that IL- $\alpha$ and TNF $\alpha$ act synergistically to stimulate GM-CSF and G-CSF production by cultured marrow stromal cells. We further show that $\mathrm{IL}-1 \alpha$ and TNF $\alpha$ synergistically stimulate production of GM-CSF and G-CSF by a clonal stroma-derived cell strain. Although IL-1 and TNF share many of the same biological activities, we show that IL-1 $\alpha$ and TNF $\alpha$ have an unequal ability to induce myeloid-CSF production by both cultures, with IL-1 $\alpha$ being the more potent inducer. We found that induction by IL-1 $\alpha$ and TNF $\alpha$ was independent of cell proliferation. The effect of IL-1 $\alpha$ and TNF $\alpha$ on production of the two myeloidCSFs by the clonal cells was significantly greater than the unfractionated passaged stromal cultures, having the greater effect on G-CSF production. The clonally derived stromal cells constitutively produced colony-stimulating activity, in particular GM-CSF, at levels easily detected by ELISA. These findings show that, in addition to the overlapping and additive activities of IL-1 $\alpha$ and TNF $\alpha$, they can interact synergistically. Our findings further suggest that a small subpopulation of stroma cells may be the major producer of G-CSF in the marrow microenvironment during immune response. (c) 1994 Wiley-Liss, Inc.
\end{abstract}

Development of blood cells in the marrow occurs in close association with marrow mesenchymal cells termed bone marrow stromal cells. The marrow stroma is a complex tissue that is made up of many different cell types that include fibroblasts, adipocytes, endothelial cells, and macrophages (Dorshkind, 1990). Stromal cell-derived cytokines are a major component in the pathways that regulate blood cell survival, proliferation, and differentiation (Singer and Keating, 1983; Gualtieri et al., 1984; Heard et al., 1982; Shadduck et al., 1983; Tsai et al., 1986; Zucali et al., 1987; Yang et al., 1988). Uninduced cultured stromal cells release little, if any, detectable hematopoietic growth factors (HGFs) into the culture supernatant (Kittler et al., 1992; Guba et al., 1992). However, when stimulated with the inflammatory mediators interleukin-1-alpha (IL-1 $\alpha)$ or tumor necrosis factor-alpha (TNF $\alpha$ ), increased levels of soluble HGFs are found in stromal cultures supernatants.

Although IL-1 and TNF are unrelated in their amino acid sequences and known to recognize different receptors (Aggarwal et al., 1985; Beutler and Cerami, 1985; Matsushima et al., 1986), they display many of the same biological activities (Dinarello, 1989; Vassalli, 1992; Le and Vilcek, 1987). One possible consequence of this apparent evolutionary convergence is that stimu- lation with IL-1 versus TNF could theoretically result in subtle distinct physiologic responses. However, in many cases both TNF and IL-1 appear to be triggered by a common afferent signal. A second interesting possibility is that IL-1 and TNF actually work synergistically on at least some of their target cells. This molecular scenario would result in a significant expansion of the range of physiologic responses only at the cells which were targets for this synergy.

We therefore asked whether TNF $\alpha$ and IL-1 $\alpha$ might induce bone marrow stromal cells to secrete either granulocyte-macrophage colony-stimulating factor (GM-CSF), granulocyte colony-stimulating factor (GCSF), or both in a supra-additive or synergistic fashion. We now report that interleukin- $1 \alpha$ and TNF $\alpha$ interact synergistically to stimulate production of GM-CSF and G-CSF by cultured human bone marrow stromal cells. When co-stimulated with IL-1 $\alpha$ and TNF $\alpha$, stroma cultures produce supra-additive levels of GM- and G-CSF compared to levels induced by either cytokine alone. In addition, we have found that IL-1 $\alpha$ and TNF $\alpha$ interact

Received June 28, 1993; accepted November 5, 1993.

*To whom reprint requests/correspondence should be addressed. 
synergistically to stimulate GM-CSF and G-CSF production by a human marrow stroma-derived cell strain. These data indicate that IL-1 $\alpha$ and TNF $\alpha$ interact synergistically to stimulate HGF production by marrow stromal cells, and thereby identify a novel mechanism for amplification of the inflammatory response by combining afferent limb monokines.

\section{MATERIALS AND METHODS Cells}

Normal human bone marrow was obtained by aspiration from healthy adult volunteers, after informed consent, under a protocol approved by the University of Michigan Institutional Review Board.

\section{Bone marrow stromal cell cultures}

Bone marrow stromal (BMS) cell cultures were established from liquid cultures of mononuclear cells isolated by centrifugation over Ficoll-Hypaque (density $1.077 \mathrm{~g} / \mathrm{mL}$; Pharmacia, Piscataway, NJ) and the stromal cells separated by adherence to tissue culture plastic. The cells were grown to confluence in Iscove's modified Dulbecco's medium (Gibco, Grand Island, NY) supplemented with 10\% fetal bovine serum (Hyclone Laboratories, Logan, UT), 10\% horse serum (Hyclone, Logan, UT), $10^{-5} \mathrm{M}$ hydrocortisone (Sigma Chemicals, St. Louis, MO), 1\% Pen/Strep (Sigma Chemicals, St. Louis, MO), with $50 \%$ fresh medium exchange twice weekly, removing nonadherent cells with each exchange. Cultures were maintained at $37^{\circ} \mathrm{C}$ in a humidified environment with $5 \% \mathrm{CO}_{2}$. Only early passaged (two to eight passages) BMS cells were used in the experiments described in this study. Experimental cultures were seeded at low density $\left(1 \times 10^{4}\right.$ cells $\left./ \mathrm{mL}\right)$ in six-well tissue culture plates (Costar, Cambridge, MA) and grown to visual confluence before initiation of experimental conditions.

\section{Colony-derived stromal cell strains}

The stroma-derived cell strains (CDCL) used in this study were generously provided by Jack Singer (VA Medical Center, Seattle, WA). CDCL cultures were established as previously described (Singer, 1989). Briefly, stromal cell cultures maintained in vitamin and amino acid enriched McCoy's 5A medium, supplemented with $12.5 \%$ fetal bovine serum, $12.5 \%$ horse serum, $0.036 \%$ hydrocortisone, $1 \% \mathrm{Pen} / \mathrm{Strep}$, were trypsinized and plated at low density $(25-30,000$ cell/ $\mathrm{ml}$ ) in $2.5 \%$ methylcellulose supplemented with IL-1 $\alpha$ $(25 \mathrm{U} / \mathrm{mL})$ and $\mathrm{TNF} \alpha(100 \mathrm{U} / \mathrm{mL})$. After 2 weeks, colonies are plucked from the methylcellulose medium and added to liquid medium in the presence of basic-Fibroblast Growth Factor (b-FGF) $(10 \mathrm{ng} / \mathrm{mL})$ to re-establish adherent cell cultures. Only early passaged (four to ten passages) CDCL cells were used in the experiments described in this study. Experimental cultures were seeded at low density $\left(1 \times 10^{4}\right.$ cells $\left./ \mathrm{mL}\right)$ in six-well tissue culture plates (Costar, Cambridge, MA) or T-25 cm flasks (Corning, Corning, NY) and grown to visual confluence before initiation of experimental conditions.

\section{Cytokines}

Recombinant human IL-1 $\alpha$, TNF $\alpha$, GM-CSF, and erythropoietin were obtained from R \& D Systems
(Minneapolis, MN). Bladder carcinoma cell (5637) conditioned medium was a gift from Micheal Clarke (Department of Internal Medicine, University of Michigan).

\section{Colony-stimulating factor measurements}

GM-CSF and G-CSF concentrations in experimental culture supernatants were determined by enzymelinked immunosorbent assay (ELISA) (R \& D Systems, Minneapolis, MN). ELISA optical densities were measured and analyzed by an ELISA plate reader (Molecular Devices Corp., Menlo Park, CA) interfaced with an IBM computer using the Softmax program (Molecular Devices Corp., Menlo Park, CA). The ranges of cytokine detection in the ELISA were 1.5-750 pg/mL (GM-CSF) and $7.2-5,000 \mathrm{pg} / \mathrm{mL}$ (G-CSF).

\section{Colony-stimulating activity bioassay}

Conditioned media were assayed for production of colony-stimulating activity (CSA) by colony-forming assay. Ficoll-Hypaque isolated marrow mononuclear cells were plated in methylcellulose (Terry Fox Laboratories, Vancouver, B.C., Canada), supplemented with either recombinant erythropoietin $(2 \mathrm{U} / \mathrm{mL})$ and GMCSF (20 ng/mL), conditioned medium from bladder carcinoma cells (5637), or $72 \mathrm{hr}$-conditioned medium from uninduced bone marrow stromal cell cultures.

\section{RESULTS \\ IL-1 $\alpha$ and TNF $\alpha$ synergistically stimulate bone marrow stromal cells to produce G-CSF and GM-CSF}

To evaluate the effect of IL-1 $\alpha$ and TNF $\alpha$ on production of G-CSF and GM-CSF by human BMS cells, we stimulated confluent cultures of multiply passaged cells with either IL-1 $\alpha$ or TNF $\alpha$ alone, or both simultaneously. To determine optimal concentrations of IL-1 $\alpha$ and TNF $\alpha$ for stimulating G-CSF and GM-CSF production, BMS cultures were stimulated individually with either IL-1 $\alpha$ or TNF $\alpha$ at varying concentrations (Fig. 1). Although the relative levels of IL-1 $\alpha$ induced G-CSF and GM-CSF were significantly different, with G-CSF being higher, the optimal IL-1 $\alpha$ concentration for inducing both CSFs was the same (Fig. 1A). TNF $\alpha$ was less effective than $\mathrm{IL}-1 \alpha$ at inducing G-CSF and GMCSF production by BMS cultures. Unlike IL-1 $\alpha$, however, TNF $\alpha$ was more effective in stimulating production of GM-CSF than G-CSF over the concentration range tested (Fig. 1B).

When added together at an optimal concentration, IL-1 $\alpha(5-25 \mathrm{U} / \mathrm{mL})$ and TNF $\alpha(50-100 \mathrm{U} / \mathrm{mL})$ elicit secretion of both G-CSF and GM-CSF to levels significantly greater than either cytokine alone. In order to demonstrate synergy, the response to two agents must be greater than twice the response of each individual agent. Bone marrow stromal cell cultures stimulated individually with $\mathrm{IL}-1 \alpha(25 \mathrm{U} / \mathrm{mL})$ or TNF $\alpha(100 \mathrm{U} / \mathrm{mL})$ released $1,800 \mathrm{pg} / \mathrm{mL}$ and $<10 \mathrm{pg} / \mathrm{ml}$ of G-CSF into the culture supernatant, respectively. When stimulated with IL- $1 \alpha$ and TNF together, however, stromal cells released 5,225 $\mathrm{pg} / \mathrm{ml} \mathrm{G-CSF}$ into the culture supernatant (Fig. 2A). Similarly, GM-CSF production by stromal cells stimulated with IL-1 $\alpha$ and TNF $\alpha$ was only $27.5 \mathrm{pg} / \mathrm{ml}$ and $<8 \mathrm{pg} / \mathrm{ml}$, respectively. Stromal cell cul- 

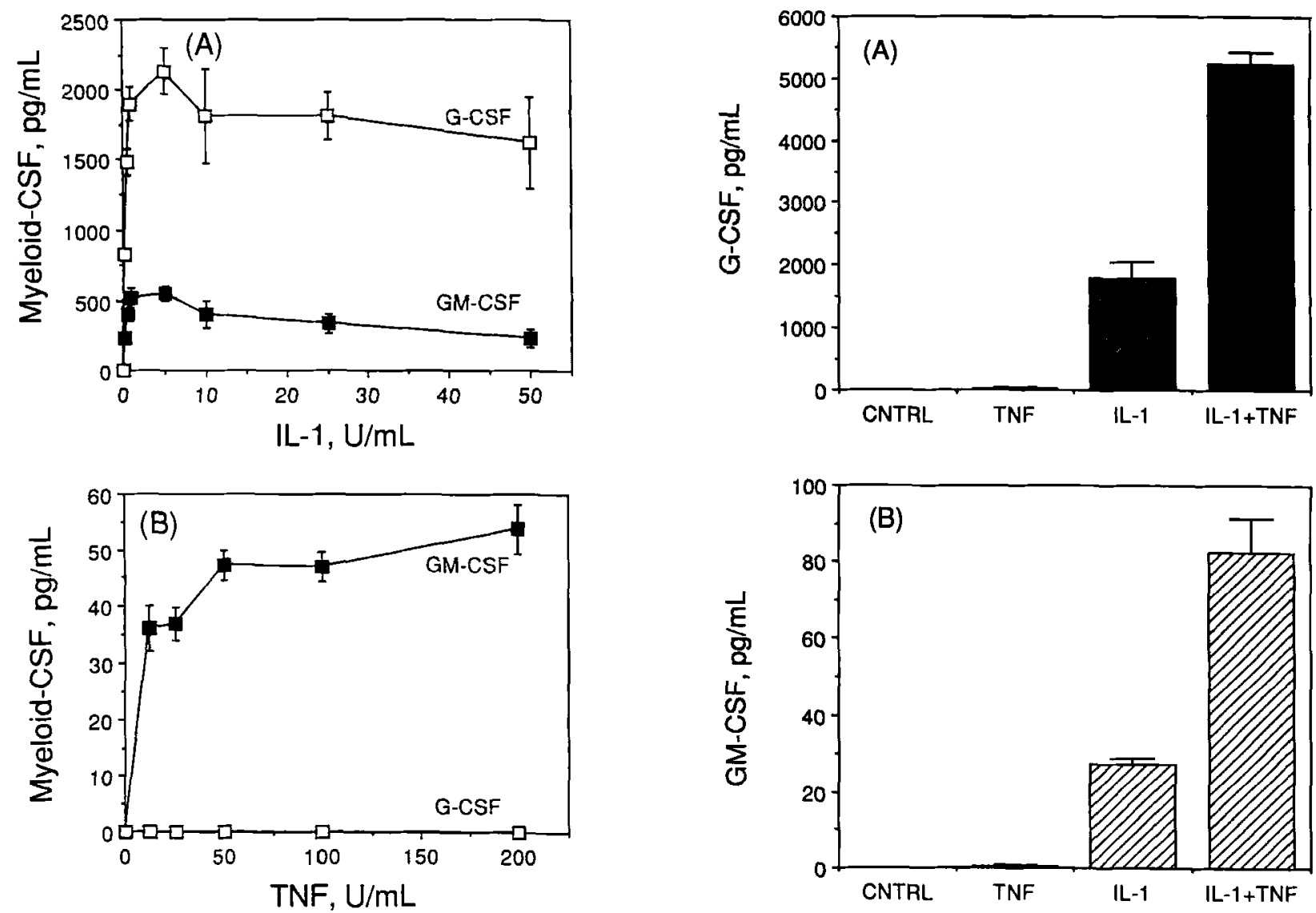

Fig. 1. Dose response of BMS cells to IL-1 $\alpha$ and TNF $\alpha$. Confluent BMS cultures were stimulated for $24 \mathrm{hr}$ with varying concentrations of IL-1 $\alpha$ (A) or TNF $\alpha$ (B). G-CSF (open squares) and GM-CSF (filled squares) concentrations in the culture supernatants were determined by ELISA. The mean \pm SD are shown for triplicate cultures.

tures that were simultaneously stimulated with IL-1 $\alpha$ and TNF $\alpha$ released $82.3 \mathrm{pg} / \mathrm{ml}$ GM-CSF into culture supernatants (Fig. 2B), representing nearly a threefold increase in GM-CSF production compared to IL-1 $\alpha$ alone and greather than tenfold increase over TNF $\alpha$ alone. Therefore, IL-1 $\alpha$ is a much more potent inducer of myeloid-CSF production by BMS cells than TNF $\alpha$, but co-stimulation with both cytokines results in synergistic production of G-CSF and GM-CSF.

\section{IL- $\alpha$ and TNF $\alpha$ synergistically stimulate a marrow stroma-derived cell strain to produce G-CSF and GM-CSF}

We next asked if the synergistic interaction observed between IL- $1 \alpha$ and TNF $\alpha$ in stimulating whole, multiply passaged BMS cells to secrete myeloid-CSFs could be observed in a homogeneous, cytokine producing population of BMS cells. For these experiments we used a clonally derived human bone marrow stroma-derived cell strain (CDCL) (isolated as described in Materials and Methods). As previously described by Singer (1989), these clonally derived cells constitutively release measurable quantities of CSA into the culture supernatants, at levels similar to those detected in 5637

Fig. 2. Cytokine induced myeloid-CSF production by BMS cells. Confluent BMS cultures were stimulated for $24 \mathrm{hr}$ with either IL-1 $\alpha$ (25 $\mathrm{U} / \mathrm{mL}), \mathrm{TNF} \alpha(100 \mathrm{U} / \mathrm{mL}), \mathrm{IL}-1 \alpha$ and TNF $\alpha$ together, or medium only (control). The concentrations of G-CSF (A) and GM-CSF (B) in the culture supernatant were determined by ELISA. The mean \pm SD are shown for triplicate cultures.

TABLE 1. CDCL cell conditioned medium CSA assay

\begin{tabular}{lc}
\hline $\begin{array}{l}\text { Conditioned } \\
\text { medium }^{1}\end{array}$ & $\begin{array}{c}\text { Number of } \\
\text { progenitor cells }\end{array}$ \\
\hline CDCL & $164 \pm 39.6$ \\
5637 & $196 \pm 12.1$ \\
rhEpo + rhGM-CSF & $105 \pm 48.3$ \\
Control & $24 \pm 10.4$ \\
\hline
\end{tabular}

${ }^{1}$ The final concentration of conditioned media and control medium (Iscove's modified Dulbecco's medium $+20^{\circ} \%$ fetal bovine serum) was $10 \%$ \% $v / v$. Concentrations in recombiDulbecco's medium $+20 \%$ fetal bovine serum) was 10 so
nant cytokines are described in Material and Methods.

${ }^{2}$ Results are expressed as the number of hematopoietic progenitor cells per $10^{5}$ bone marrow mononuclear cells plated. Each value represents the mean \pm SD of three assay wells.

cell conditioned medium. Conditioned medium from CDCL cell cultures was just as effective as recombinant GM-CSF and erythropoietin in supporting hematopoietic progenitor cell proliferation in a colony-forming assay (Table I). When stimulated with IL-1 $\alpha(25 \mathrm{U} / \mathrm{mL})$ or TNF $\alpha(100 \mathrm{U} / \mathrm{mL})$ individually, CDCL cells released significantly higher levels of G-CSF and GM-CSF into the culture supernatant than did the unfractionated stromal cell cultures. IL- $1 \alpha$ stimulated CDCL cells produced greater than $10.8 \mathrm{ng} / \mathrm{ml} \mathrm{G-CSF}$ and $7.6 \mathrm{ng} / \mathrm{ml}$ 

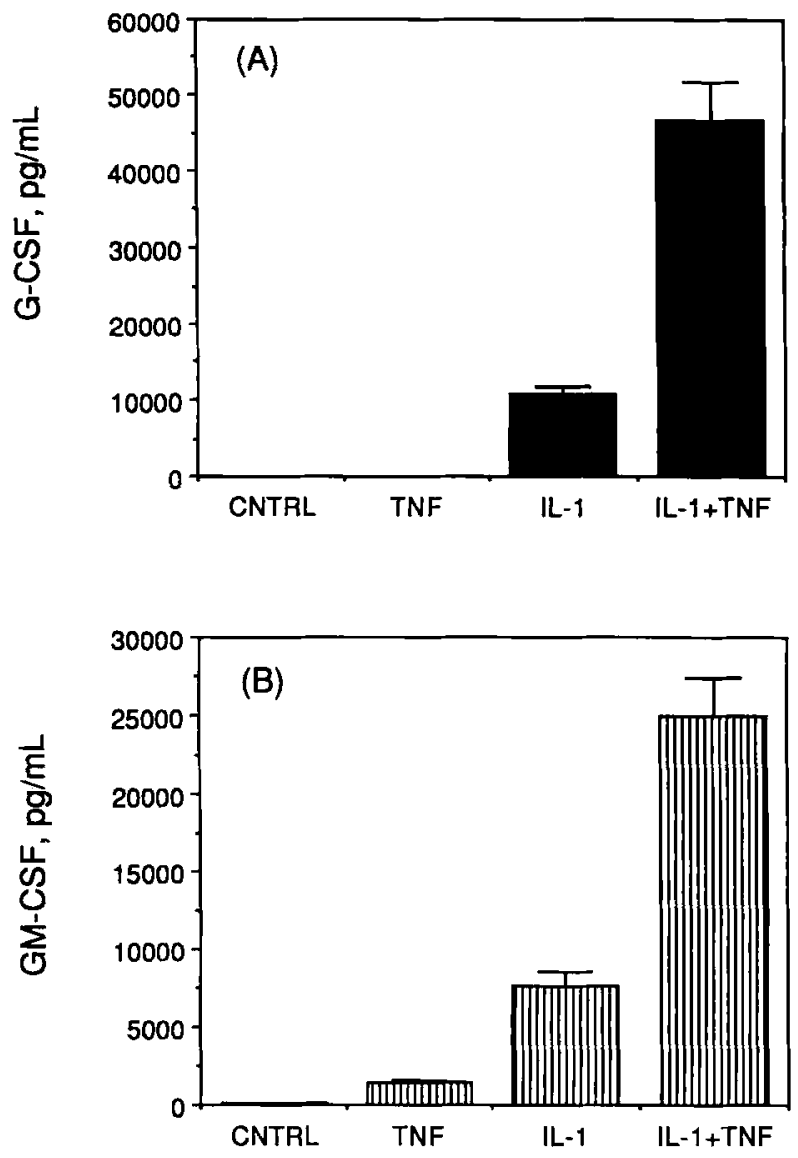

Fig. 3. Cytokine induced myeloid-CSF production by CDCL. Confluent cultures of bone marrow CDCL were stimulated for $24 \mathrm{hr}$ with either IL $-1 \alpha(25 \mathrm{U} / \mathrm{mL}), \mathrm{TNF} \alpha(100 \mathrm{U} / \mathrm{mL}), \mathrm{IL}-1 \alpha$ and TNF $\alpha$ together, or medium only (control). The concentrations of G-CSF (A) and GMCSF (B) in the culture supernatant were determined by ELISA. The mean \pm SD are shown for triplicate cultures.

GM-CSF (Fig. 3), more than 10,000-fold and 69-fold greater production of G-CSF and GM-CSF, respectively, than unstimulated cultures. TNF $\alpha$ stimulated CDCL cultures released no detectable G-CSF into the culture medium. As with BMS cultures, $\mathrm{TNF} \alpha$ was less effective than IL- $1 \alpha$ in stimulating GM-CSF production by CDCL cells. TNF $\alpha$ induced GM-CSF production by CDCL cells was $1,488 \mathrm{pg} / \mathrm{ml}$. As with the unfractionated stromal cultures, a very large synergistic effect between IL-1 $\alpha$ and TNF $\alpha$ was observed in the CDCL cultures; cultures co-stimulated with both cytokines produced $46.5 \mathrm{ng} / \mathrm{ml} \mathrm{G-CSF}$ and $25 \mathrm{ng} / \mathrm{ml}$ GM-CSF, respectively (Fig. 3).

To determine if the difference in levels of IL-1 $\alpha$ and TNF $\alpha$ induced G-CSF and GM-CSF production by BMS and CDCL cells could be due to a difference in optimal IL- $1 \alpha$ and TNF $\alpha$ concentration, we next performed a dose-response analysis. Similar to the dose response results obtained with whole BMS cells, we found a significant difference in the relative magnitude of cytokine induced G-CSF and GM-CSF produced by the CDCL cultures. However, the optimal IL- $1 \alpha$ and TNF $\alpha$ concentrations for achieving maximal production of
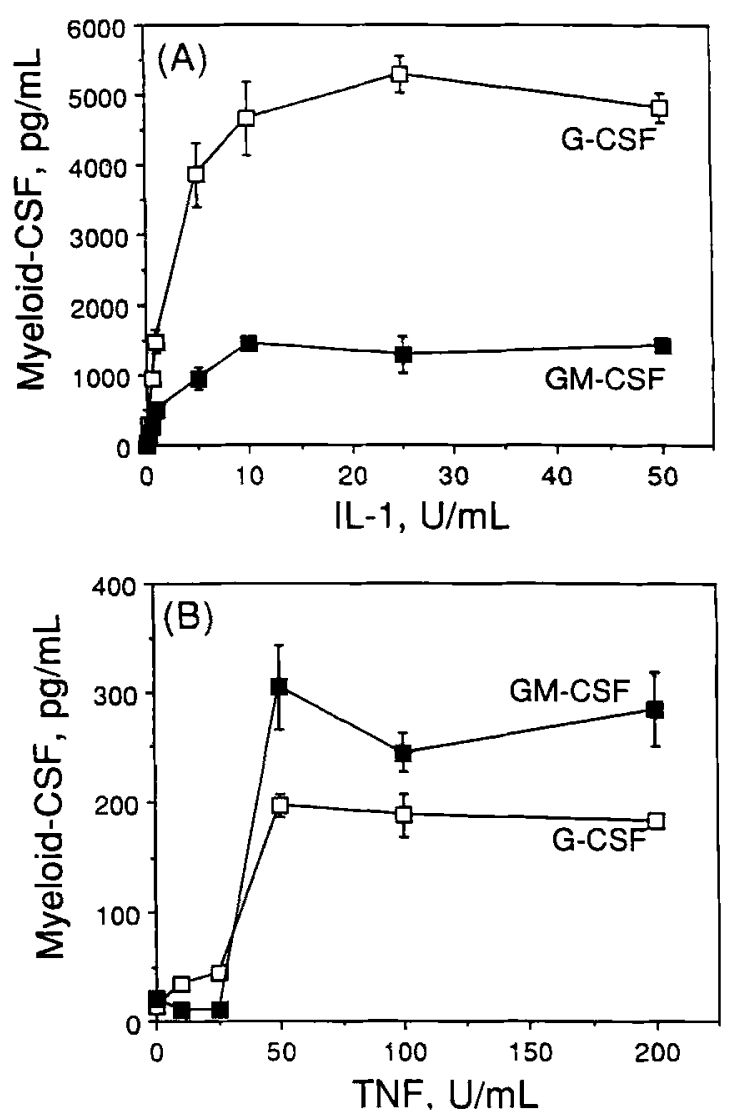

Fig. 4. Dose response of CDCL to IL-1 $\alpha$ and TNF $\alpha$. Confluent CDCL cultures were stimulated for $12 \mathrm{hr}$ with varying concentrations of $\mathbb{L}-1 \alpha(A)$ or TNF $\alpha(B)$. G-CSF (open squares) and GM-CSF (filled squares) concentrations in the culture supernatants were determined by ELISA. The mean \pm SD are shown for triplicate cultures.

G-CSF and GM-CSF were the same as for the BMS cultures (Fig. 4).

\section{IL-1 $\alpha$ and TNF $\alpha$ mitogenic effect}

We next asked whether the stimulatory effect of IL-1 $\alpha$ and TNF $\alpha$ on G-CSF and GM-CSF production could be explained, in part, by a significant expansion in cell number. There are several reports that show IL-1 and TNF can, under some conditions, induce some cell types (e.g., fibroblasts, smooth muscle cells, and macrophages) to undergo mitogenic proliferation (Branch et al., 1989; Sugarman et al., 1985; Dukovich et al., 1986; Vilcek et al., 1986; Schmidt et al., 1982; Dinarello, 1985; Kohase et al., 1986; Ikeda et al., 1990). We found, however, that neighter IL-1 $\alpha$ or TNF $\alpha$ alone nor the two together resulted in a significant increase in cell number in either BMS cultures or CDCL cultures. After a 72-hr stimulation, under each condition, less than one culture doubling was observed (Table II). Therefore, it appears that the increased CSF production, in particular the synergistic stimulation of GMand G-CSF secretion, was the result of increased production on a per cell basis. 


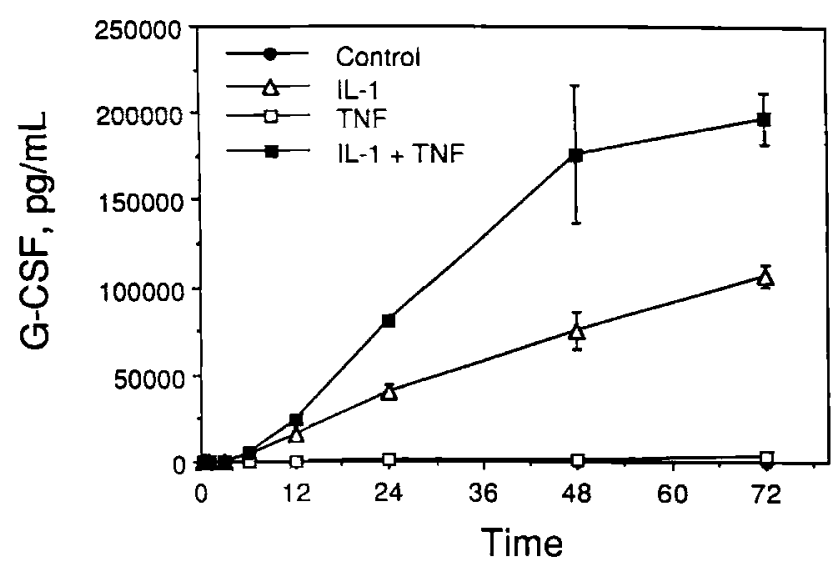

Fig. 5. Kinetics of G-CSF production by CDCL. Confluent CDCL cultures were stimulated with either IL-1 $\alpha(25 \mathrm{U} / \mathrm{mL})$, TNF $\alpha(100$ $\mathrm{U} / \mathrm{mL}$ ), IL-1 $\alpha$ and TNF $\alpha$ together, or medium only (control). Aliquots of the culture supernatants were removed at $1,3,6,12,24,48$, and 72 $\mathrm{hr}$ for determination of G-CSF concentration. The mean $\pm \mathrm{SD}$ are shown for triplicate cultures.

\section{Kinetics of myeloid-CSF production by a stromal-derived cell strain}

In the experiments described aboved, the production of myeloid-CSFs was determined via supernatant assays, obtained after 12 or $24 \mathrm{hr}$ of stimulation. We next asked whether the apprent synergy between IL-1 $\alpha$ and $\mathrm{TNF} \alpha$ reflected an acceleration in production kinetics. For this experiment we used confluent CDCL cultures stimulated as before, by removing small aliquots of supernatants at various times over a $72-\mathrm{hr}$ period and determining the concentration of G-CSF. Not until about $6-8 \mathrm{hr}$ of stimulation could we begin to detect an increase in G-CSF levels. Similarly, not until about 12 hr of stimulation could we begin to detect synergy between IL-1 $\alpha$ and TNF $\alpha$. Interestingly, whereas the levels of the respective cytokine induced G-CSF were significantly different over the first $24 \mathrm{hr}$, the respective rates of production were very similar. Also, only the level of G-CSF in the IL- $1 \alpha+$ TNF stimulated cultures appeared to approach a plateau after $72 \mathrm{hr}$ (Fig. 5). Therefore, the observed synergy did not result in a significant acceleration in secretion kinetics for either $\mathrm{IL}-1 \alpha$ or $\mathrm{TNF} \alpha$.

\section{DISCUSSION}

In this study, we demonstrate that IL $\alpha$ and TNF $\alpha$ act synergistically to stimulate human bone marrow stromal (BMS) cells to produce GM-CSF and G-CSF. We further demonstrate that IL-1 $\alpha$ and TNF $\alpha$ act synergistically to stimulate cultures of a human bone marrow stroma-derived cell strain (CDCL) to produce GM-CSF and G-CSF. Our data show that in both cultures, IL-1 $\alpha$ was a more potent inducer of cytokine secretion than TNF $\alpha$, and cultures stimulated with IL-1 $\alpha$ alone secreted much higher levels of G-CSF into the culture supernatant than GM-CSF. TNF $\alpha$, though less potent than IL-1 $\alpha$, was more effective in stimulating production of GM-CSF than G-CSF. In some instances, TNF $\alpha$ failed to stimulate secretion of detectable levels of G-CSF into the culture supernatant. This may, in part,
TABLE 2. Mitogenic effect of IL-1 $\alpha$ and TNF $\alpha$ on BMS and CDCL cells ${ }^{1}$

\begin{tabular}{lcc}
\hline & \multicolumn{2}{c}{ Number of culture doublings } \\
\cline { 2 - 3 } Cytokines & BMS & CDCL \\
\hline None & 0.6 & 0.5 \\
TNF $\alpha$ & 0.6 & 0.4 \\
IL- $\alpha \alpha$ & 0.5 & 0.3 \\
L-1 $\alpha+\mathrm{TNF}_{\alpha}$ & 0.3 & -0.2 \\
\hline
\end{tabular}

${ }^{\mathrm{I}}$ Confluent replicate cultures of BMS and CDCL cells were cultivated for $72 \mathrm{hrs}$ in a medium of Iscove's modified Dulbecco's medium $+20 \%$ fetal bovine serum (control medjum), with the addition of either IL-1 $\alpha(25 \mathrm{U} / \mathrm{mL})$, TNF $\alpha(100 \mathrm{U} / \mathrm{mL})$, or $\mathrm{IL}-1 \alpha$ and TNF $\alpha$ together. Culture adherent layers were trypsinized and cell densities determined by hemacytometer.

${ }^{2}$ Culture doubling is the fractional increase in cell density after cytokine stimulation relative to the cell density of representative cultures at the start of stimulation. Results are expressed as the mean cell density of three cultures.

be due to variation between stromal cells from different bone marrow donors. However, in all cases co-stimulation with IL-1 $\alpha$ and TNF $\alpha$ caused secretion of G-CSF to levels significantly greater than those observed with IL-1 $\alpha$ alone.

Although the patterns of IL-1 $\alpha$ and TNF $\alpha$ induction of cytokine production were similar for the BMS and CDCL cultures, stimulated CDCL cultures secreted significantly higher levels of GM- and G-CSF into the culture supernatant than did stimulated BMS cultures. The respective IL-1 $\alpha$ and $\mathrm{TNF} \alpha$ dose response curves for BMS and CDCL cultures were nearly identical, thus ruling out a difference in maximally stimulating concentrations of IL-1 $\alpha$ and $\mathrm{TNF} \alpha$ as an explanation for the disparity in CSF production levels. Likewise, unstimulated CDCL cultures constitutively secreted detectable levels of GM-CSF into the culture supernatant and, on occasion, G-CSF, whereas unstimulated BMS cultures did not.

Mitogenic activity has been attributed to both IL-1 and TNF. However under the conditions used in this study, neither monokine caused a significant increase in cell number (Table II), suggesting that the increase in cytokine production observed in the cultures was due to increased production per cell. These data demonstrate that mitogenic activity by IL- $\alpha$ and TNF $\alpha$ is not required for stimulation of myeloid-CSF production by human bone marrow stromal cells.

These data taken together suggest that a subset of bone marrow stromal cells, represented by CDCL cells, may be a major source of G-CSF and, to a lesser degree, GM-CSF in the marrow microenvironment. The proposition of marrow stromal cell heterogeneity is supported by a recent report by Ozawa et al. (1991), who showed, using in situ hybridization, that a subpopulation of bone marrow stromal cells appears to be the main source of G-CSF. The present results should be considered in light of previous studies of the effects of IL -1 and TNF on diverse mesenchymal cell responses. To compliment their individual pleiotropic affects, IL-1 and TNF have been shown to interact with other cytokines, as well as with each other, in an additive and sometimes supra-additive manner (Branch et al., 1989; Seelentag et al., 1987; Nakagawa et al., 1989; Leizer et al., 1990; Elias et al., 1988; Wankowicz et al., 1988; Male and Pryce, 1988; Brach et al., 1992; Hoang et al., 1989; Chantry et al., 1989; Tanner et al., 1992; Stashenko et al., 1987; Mandrup-Poulsen et al., 1987; Brox- 
meyer et al., 1986). In particular, Wankowicz et al. (1988) found that IL-1 and TNF synergistically stimulated leukocyte migration during inflammation and Stashenko et al. (1987) found that IL-1 $\alpha$ and TNF $\alpha$ stimulated bone resorption with apparently supra-additive kinetics. Similar to the IL-1/TNF synergy seen in the present study with bone marrow stromal cells, Leizer et al. (1990) reported finding synergy between IL- $1 \alpha / \beta$ and TNF $\alpha / \beta$ in stimulating production of GMCSF and G-CSF by human synovial fibroblasts in vitro. Synergy between IL-1 and TNF has been observed in in vivo studies as well: Movat et al. (1987) observed that IL-1 $\alpha$ or $\beta$ in combination with TNF $\alpha$ synergistically induced inflammation and microvascular injury in rabbits, and Okusawa et al. (1988) observed synergistic induction of a severe shock-like state in rabbits when injected with IL-1 $\beta$ and TNF $\alpha$.

Within the hematopoietic system, there have been several reports of IL-1 and TNF inducing hematopoietic growth factor (HGF) production, especially GM-CSF, and in some cases, G-CSF (Hamilton et al., 1992; Akashi et al., 1989; Koeffler et al., 1987; Munker et al., 1986; Fibbe et al., 1988; Lee et al., 1987; Sieff et al., 1987, 1988; Kaushansky et al., 1988; Bagby et al., 1986; Broudy et al., 1986; Zucali et al., 1986; Zoellner et al., 1982) by mesenchymal cells such as fibroblasts, endothelial cells, and smooth muscle cells. To what extent IL-1 $\alpha$ and TNF $\alpha$ synergy occurs in vivo is not clear at this time. In contrast to the present study, Vogel et al. (1987) reported that simultaneous injection of optimal concentrations of recombinant IL- $1 \alpha$ and TNF $\alpha$ in mice stimulated only an additive increase in colony-stimulating activity (CSA) over that observed with either cytokine alone. However, these previous studies were performed without the benefit of specific or quantitative ELISAs. One possible explanation for this apparent discrepancy is that the CSA assay is not sensitive enough to detect supra-additive levels of GM- and G-CSF production by marrow stromal cells. This might preclude the systemic observation of IL-1/TNF synergy. Taken together, these data provide further support for the importance of IL-1 and TNF in the regulation of bone marrow hematopoiesis via stimulation of marrow stromal cells.

IL-1 and TNF have been shown to be intermediates of inflammation during an immune response. The relative potency of IL-1 and TNF to induce production of GM- or G-CSF, in conjunction with their synergistic effect, suggests optional pathways for the induction of myeloid-CSFs in the marrow microenvironment. One option is to have induction by IL-1 alone. This results in a significant increase in both GM- and G-CSF, with the increase being greater for G-CSF. An alternative path has stimulation with TNF alone. This option results in an increase in GM-CSF but not G-CSF. A third option would have stimulation by both monokines, which causes a synergistic increase of both GM- and G-CSF. The unique activities of GM- and G-CSF have been well documented. GM-CSF has been shown to inhibit neutrophil migration as well as to activate mature neutrophils (Gasson et al., 1984; Vadas et al., 1983), eosinophils (Vadas et al., 1983a,b), and monocytes (Grabstein et al., 1986). G-CSF has been found to activate neutrophil toxicity (Lopez et al., 1983). Whether or not the response is primarily localized to the marrow or is systemic may determine which pathway is activated.

A recent report of synergistic interactions between cytokines and HGFs has focused more attention on synergy as a mechanism to greatly expand the biological repertoir of individual regulators of hematopoiesis (Jacobsen et al., 1992). At this time, however, little is known about the molecular basis for these synergistic interactions. Current experiments are underway to determine the molecular basis for the synergy between IL-1 $\alpha$ and TNF $\alpha$ described here, including the possibility of receptor induction, cooperative post-receptor signal transduction, and cooperative promoter binding by trans-acting factors.

\section{ACKNOWLEDGMENTS}

The authors thank Dr. Jack Singer and Carole Crittenden (VA Medical Center, Seattle, WA) for kindly providing the stroma-derived cell strains and their technical assistance with stromal cell cloning and culture procedures. SGE is a Scholar of the Leukemia Society of America and $\mathrm{JC}$ is the recipient of a Minority Investigator Research Supplement Award from NIHNHLBI. This work was supported by Grants RO1 HL42096 and RO1 HL48896 from the National Institutes of Health and the Leukemia Society of America.

\section{LITERATURE CITED}

Aggarwal, B.B, Eessalu, H., and Hass, P.E. (1985) Characterization of receptors human tumor necrosis factor and their regulation by $\mathbf{g}$ interferon. Nature, 318:665-667.

Akashi, M., Saito, M., and Koeffler, H.P. (1989) Lymphotoxin: Stimulation and regulation of colony-stimulating factors in fibroblasts. Blood, 74:2383-2390.

Bagby, G.C., Dinarello, C.A., Wallace, P., Wagner, C., Hefeneider, S., and McCall, E. (1986) Interleukin 1 stimulates granulocyte macrophage colony-stimulating activity release by vascular endothelial cells. J. Clin. Invest., 78:1316-1323.

Beutler, B.A. and Cerami, A. (1985) Recombinant interleukin 1 suppresses lipoprotein lipase activity in 3T3-L1 cells. J. Immunol., 135: 3969-3971.

Brach, M.A., Gruss, H.-J., Asano, Y., de Vos, S., Ludwig, W.-D., Metelsmann, R., and Herrmann, F. (1992) Synergy of interleukin 3 and tumor necrosis factor a in stimulating clonal growth of acute myelogenous leukemia blasts is the result of induction of secondary hematopoietic cytokines by tumor necrosis factor $\alpha$. Cancer Res, 52 : 2197-2201.

Branch, D.R., Turner, A.R, and Guilbert, L.J. (1989) Synergistic stimulation of macrophage proliferation by the monokines tumor necrosis factor-alpha and colony-stimulating factor 1. Blood, 73:307-311.

Broudy, V.C., Kaushansky, K., Segal, G.M., Harlan, J.M., and Adamson, J.W. (1986) Tumor necrosis factor type a stimulate human endothelial cells to produce grandulocyte/macrophage colony-stimulating factor. Proc. Natl. Acad. Sci. USA, 83:7467-7471.

Broxmeyer, H., Williams, D., Lu, L., Cooper, S, Anderson, S.L., Beyer, G.S., Hoffman, R., Rubin, B.Y. (1986) The suppressive influences of human tumor necrosis factors on bone marrow hematopoietic progenitor cells from normal donors and patients with leukemia: Synergism of tumor necrosis factor and interferon-gamma. J. Immunol., 136:4487-4495.

Chantry, D., Winearls, C.G., Maini, R.N., and Feldman, M. (1989) Mechanism of immune complex-mediated: Induction of interleukin 1 by immune complexes and synergy with interferon-g and tumor necrosis factor- $\alpha$. Eur. J. Immunol., 19:189-192.

Dinarello, C.A. (1985) An update on human interleukin-1: From molecular biology to clinical relevance. J. Clin. Immunol., 5:287-297.

Dinarello, C.A. (1989) Interleukin-1 and its biologically related cytokines. Adv. Immunol., 44:153-205.

Dorshkind, K. (1990) Regulation of hematopoiesis by bone marrow stromal cells and their products. Annu. Rev. Immunol., 8:111-137.

Dukovich, M., Sevrin, J.M., White, S.J., Yamazaki, S., and Mizel, S.B. (1986) Stimulation of fibroblast proliferation and postaglandin pro- 
duction by purified recombinant murine interleukin 1. Clin. Immunol. Immunopathol., 38:381-389.

Elias, J.A., Gustilo, K., and Freundlich, B. (1988) Human alveolar macrophage and blood monocyte inhibition of fibroblast proliferation. Evidence for synergy between interleukin-1 and tumor necrosis factor. Am. Rev. Respir. Dis., 138:1595-1603.

Fibbe, W.E., van Damme, J., Billiau, A., Goselink, H.M., Voogt, P.J., van Eeden, G., Ralph, P., Altrock, B.W., and Falkenburg, J.H. (1988) Interleukin 1 induces human marrow stromal cells in longterm culture to produce grandulocyte colony-stimulating factor and macrophage colony-stimulating factor. Blood, 71:430-435.

Gasson, J.C., Weisbart, R.H., Kaufman, S.E., Clark, S.C., Hewick, R.M., Wong, G.G., and Golde, D.W. (1984) Purified human granulocyte-macrophage colony-stimulating factor: Direct action on neutrophils. Science, 226:1339-1342.

Grabstein, K.H., Urdal, D., Tushinski, R.J., Mochizuki, D.Y., Price, V.L., Cantrell, M.A., Gillis, S., and Conlon, P.J. (1986) Induction of macrophage tumoricidal activity by granulocyte-macrophage colony-stimulating factor. Science, 232:506-508.

Gualtieri, R.J., Shadduck, R.K., Baker, D.G., and Quesenberry, P.J. (1984) Hematopoietic regulatory factors produced in long-term murine bone marrow cultues and the effect of in vitro irradiation. Blood, 764:516-525.

Guba, S.C., Sartor, C.I., Gottshalk, L.R., Ye-Hu, J., Mulligan, T., and Emerson, S.G. (1992) Bone marrow stromal fibroblasts secrete interleukin-6 and grandulocyte-macrophage colony-stimulating factor in the absence of inflammatory stimulation: Demonstration by serum-free bioassay, enzyme-linked immunosorbent assay, and reverse transcriptase polymerase chain reaction. Blood, 80:11901198.

Hamilton, J.A., Piccoli, D.S., Cebon, J., Layton, J.E., Rathanaswani, P., McColl, S.R., and Leizer, T. (1992) Cytokine regulation of colonystimulating factor (CSF) production in cultured human synovial fibroblasts. II. Similarities and differences in the control of interleukin-1 induction of grandulocyte-macrophage CSF and grandulocyteCSF production. Blood, 79:1413-1419.

Heard, J.-M., Fichelson, S., and Varat, B. (1982) Role of colony-stimulating activity in murine long-term bone marrow cultures: Evidence for its production and consumption by the adherent cells. Blood, 59:761-767.

Hoang, T., Levy, B., Onetto, N., Haman, A., and Rodriguez-Cimadevilla, J.C. (1989) Tumor necrosis factor a stimulates the growth of the clonogenic cells of acute myeloblastic leukemia in synergy with granulocyte/macrophage colony-stimulating factor. $J$. Exp. Med., 170:15-26.

Ikeda, U., Ikeda, M., Oohara, T., Kano, S., and Yaginuma, T. (1990) Mitogenic action of interleukin- $\alpha$ on vascular smooth muscle cells mediated by PDGF. Artheriosclerosis, 84:183-188.

Jacobsen, S.E.W., Ruscetti, F.W., Dubois, C.M., Wine, J., and Keller, J.R. (1992) Induction of colony-stimulating factor receptor expression on hematopoietic progenitor cells: Proposed mechanism for growth factor synergism. Blood, 80:678-687.

Kaushansky, K., Lin, N., and Adamson, J.W. (1988) Interleukin 1 stimulates fibroblasts to synthesize grandulocyte-macrophage and grandulocyte colony-stimulating factors: Mechanism for the hematopoietic response to inflammation. J. Clin. Invest., 81:92-97.

Kittler, E.L.W., McGrath, H., Temeles, D., Crittenden, R.B., Kister, V.K., and Quesenberry, P.J. (1992) Biological significance of constitutive and subliminal growth factor production by bone marrow stroma. Blood, 79:3168 3178.

Koeffler, H.P., Gasson, J., Ranyard, J., Souza, L., Shepard, M. and Muncker, R. (1987) Recombinant human TNF $\alpha$ stimulates production of grandulocyte colony-stimulating factor. Blood, 70:55-59.

Kohase, M., Henriksen-DeStefano, D., May, L.T., Vilcek, J., and Pravinkumar, B.S. (1986) Induction of $\beta 2$-interferon by tumor necrosis factor: A homeostatic mechanism in the control of cell proliferation. Cell, 45:659-666.

Le, J. and Vilcek, J. (1987) Tumor Necrosis Factor and Interleukin 1: Cytokines with multiple overlapping biological activities. Lab. Invest., 56:234-248.

Lee, M., Segal., G.M., and Bagby, G.C. (1987) Interleukin-1 induces human marrow-derived fibroblasts to produce multilineage hematopoietic growth factors. Exp. Hematol., 15:983-988.

Leizer, T., Cebon, J., Layton, J.E., and Hamilton, J.A. (1990) Cytokine regulation of colony-stimulating factor production in cultured human synovial fibroblasts: I. Induction of GM-CSF and G-CSF production by interleukin-1 and tumor necrosis factor. Blood, 76:1989 1996.

Lopez, A.F., Nicola, N.A., Burgess, A.W., Metcalf, D., Battye, F.L.,
Sewell, W.A., and Vadas, M. (1983) Activation of granulocyte cytotoxic function by purified mouse colony stimulating factors. J. Immunol., 131:2983-2988.

Male, D. and Pryce, G. (1988) Synergy between interferons and monokines in MHC induction on brain endothelium. Immunol. Lett., 17:267-271.

Mandrup-Poulsen, T., Bendtzen, K., Dinarello, C.A., and Nerup, J (1987) Human tumor necrosis factor potentiates human interleukin 1-mediated rat pancreatic b-cell cytotoxicity. J. Immunol., 139: $4077-4082$

Matsushima, K., Akahoshi, T., Yamada, M., Furutani, Y., and Oppenhheim, J.J. (1986) Properties of a specific interleukin 1 (IL-1) receptor on human Epstein-barr virus-transformed B lymphocytes: Identity of the receptor for IL-1- $\alpha$ and IL-1- $\beta$. J. Immunol, 136 . 4496-4502.

Movat, H.Z., Burrowes, C.E., Cybulsky, M.I., and Dinarello, C.A. (1987) Acute inflammation and a Shwartzman-like reaction induced by interleukin-1 and tumor necrosis factor: Synergistic action of the cytokines in the induction of inflammation and microvascular injury. Am. J. Pathol., 129:463-476.

Munker, R., Gasson, J., Ogawa, M., and Koeffler, H.P. (1986) Recombinant human TNF induces production of grandulocyte-monocyte colony-stimulating factor. Science, 323:79-82.

Nakagawa, H., Miyai, H., Hirata, M., Watanabe, K., and Onuma, I (1989) Synergism between interleukin-1 $\beta$ and tumor necrosis factor- $\alpha$ in production by $3 \mathrm{~T} 3$ cells of a chemotactic factor for rat polymorphonuclear leukocytes. Inflammation, 13:553-559.

Okusawa, S., Gelfand, J.A., Ikejima, T., Connally, R.J., and Dinarello, C.A. (1988) Interleukin 1 induces a shock-like state in rabbits. Synergism with tumor necrosis factor and the effect of cyclooxygenase inhibition. J. Clin. Invest., $81: 1162-1172$.

Ozawa, K., Takahasi, K., Nishikawa, M., Yoshikubo, T., Shimane, M., Takahashi T., Takahashi, S., Horiuchi, N., Tsuruta, T., Watari, K. Tojo, A., Tani, K., and Asano, S. (1991) Regulatory production of granulocyte colony-stimulating factor (G-CSF) by stromal cells. In Hematopoietic Growth Factors: Molecular Biology to Clinical Applications of rG-CSF. P.J. Quesenberry, S. Asano, and K. Saito, eds Excerpta Medica, Tokyo, pp 55-81.

Schmidt, J.A, Mizel, S.B., Cohen, D., and Green, I. (1982) Interleukin-1, a potential regulator of fibroblast proliferation. J. Immunol. 128:2177-2182.

Seelentag, W.K., Mermod, J.-J., Montesno, R., and Vassalli, P. (1987) Additive effects of interleukin 1 and tumour necrosis factor- $\alpha$ on the accumulation of the three granulocyte and macrophage colony-stimulating factor mRNAs in human endothelial cells. EMBO J., $6: 2261-2265$

Shadduck, R.K., Waheed, A., Grenberger, J.S., and Dexter, T.M. (1983) Production of colony-stimulating factors in long-term bone marrow cultures. J. Cell. Physiol, 114:88-92.

Sieff, C.A., Tsai, S., and Faller, D.V. (1987) Interleukin 1 induces cultured human endothelial cell production of granulocyte-macrophage colony-stimulating factor. J. Clin. Invest., 79:48-51.

Sieff, C.A., Neimeyer, C.M., Mentzer, S.J., and Faller, D.V. (1988) Interleukin-1, tumor necrosis factor, and the production of colonystimulating factors by cultured mesenchymal cells. Blood, 72:13161323.

Singer, J.W. (1989) Recombinant human interleukin-6 (rhIL-1) stimulates anchorage-independent growth of marrow stromal cell (MSC) colonies which can be expanded as adherent lines that constitutively produce high levels of colony-stimulating activity (CSA). Blood, 74[Suppl]1:13a.

Singer, J.W. and Keating, A. (1983) Studies on the in vitro microenvironment in man. In Haematology and Blood Transfusion, Modern Trends in Human Leukemia. Fifth edition. R. Neth, R.C. Gallo, M.F. Greaves, M.A.S. Moore,, K. Winkles, eds. Springer-Verlag, Berlin, pp 351-354.

Stashenko, P., Dewhirst, F.E., Peros, W.J., Kent, R.L., and Ago, J.M. (1987) Synergistic interactions between interleukin 1, tumor necrosis factor, and lymphotoxin in bone resorption. J. Immunol., 138: $1464-1468$

Sugarman, B.J., Aggarwal, B.B., Hass, P.E., Figari, I.S., Palladino, M.A, and Shepaerd, H.M. (1985) Recombinant human tumor necrosis factor- $\alpha$ : Effects on proliferation of normal and transformed cells in vitro. Science, $230: 943-945$.

Tanner, W.G., Welborn, M.B., and Shepherd, V.L. (1992) Tumor necrosis factor- $\alpha$ and interleukin-1 $\alpha$ synergistically enhance phorbol myristate acetate-induced superoxide production by rat bone marrow-derived macrophages. Am. J. Respir. Cell Mol. Biol., 7:379-384. Tsai, S., Emerson, S.G., Sieff, C.A., and Nathan, D.G. (1986) Isolation 
of a human stromal cell strain secreting hemopoietic growth factors. J. Cell. Physiol., 127:137-145.

Vadas, M.A., Nicola, N.A., and Metcalf, D. (1983a) Activation of antibody dependent cell-mediated cytotoxicity of human neutrophils and eosinophils by separate colony-stimulating factors. J. Immunol., 130:795-799.

Vadas, M.A., Varigos, G., Nicola, N., Pincus, S., Dessem, A., Metcalf, D., and Battye, F.L. (1983b) Eosinophil activation by colony-stimulating factor in man: Metabolic effects and analysis by flow cytometry. Blood, 61:1232-1241.

Vassalli, P. (1992) The pathophysiology of tumor necrosis factors. Annu. Rev. Immunol., 10:411-452.

Vilcek, J., Palombella, V.J., Henriksen-DeStefano, D., Swenson, C, Feinman, R., Hirai, M., and Tsujimoto, M. (1986) Fibroblast growth enhancing activity of tumor necrosisi factor and its relationship to other polypeptide growth factors. J. Exp. Med., 163:632-643.

Vogel, S.N., Douches, S.D., Kaufman, E.N., and Neta, R. (1987) Induction of colony-stimulating factor in vivo by recombinant interleukin $1 \alpha$ and recombinant tumor necrosis factor a. J. Immunol., 138:21432148.
Wankowicz, Z., Megyeri, P., and Issekutz, A. (1988) Synergy between tumor necrosis factor $\alpha$ and interleukin-1 in the induction of polymorphonuclear leukocyte migration during inflammation. J. Leukocyte Biol., 43:349-356.

Yang, Y.-C., Tsai, S., Wong, G.G., and Clark, S.C. (1988) Interleukin-1 regulation of hematopoietic growth factor production by human stromal fiobroblasts. J. Cell. Physiol , 134:292-296.

Zoellner, H., Filonzi, E.L., Stanton, H.R., Layton, J.E., and Hamilton, J.A. (1982) Human arterial smooth muscle cells synthesize grandulocyte colony-stimulating factor in response to interleukin-1a and tumor necrosis factor- $\alpha$. Blood, 80:2805-2810.

Zucali, J.R., Dinarello, C.A., Oblon, D,J., Gross, M.A., Anderson, L., and Weiner, R.S. (1986) Interleukin 1 stimulates fibroblasts to produce grandulocyte-marophage colony-stimulating activity and prostaglandin E2. J. Clin. Invest., 77:1857-1863.

Zucali, J.R., Broxmeyer, H.E., Dinarello, C.A., Gross, M.A., and Weiner, R.S. (1987) Regulation of early hematopoietic (BFU-E and CFU-GEMM) progenitors cells in vitro by interleukin-1 induced fibroblast-conditioned medium. Blood, 69:33-37. 